\title{
Effects of Industrial Agriculture and Urbanization on Structure and Functional Organization of Macroinvertebrate of Coastal Streams in Cameroon
}

\author{
Fils Mamert Onana ${ }^{1 *}$, Antoine Arfao Tamsa ${ }^{2}$, Siméon Tchakonte ${ }^{3}$, Ernest Koji ${ }^{4}$, \\ Nectaire Lié Nyamsi Tchatcho', Yannick Nkouefuth Nfongmo', Serge Hubet Zebaze Togouet ${ }^{2}$ \\ ${ }^{1}$ Department of Aquatic Ecosystems Management, Institute of Fisheries and Aquatic Sciences, University of Douala, Douala, \\ Cameroun \\ ${ }^{2}$ Department of Animal Biology and Physiology, Faculty of Science, University of Yaoundé I, Yaoundé, Cameroon \\ ${ }^{3}$ Microbiology and Biotechnology Laboratory, Saint Jerome Polytechnic Institute, Saint Jerome Catholic University of Douala, \\ Douala, Cameroon \\ ${ }^{4}$ Department of Animal Biology and Physiology, Faculty of Sciences, University of Douala, Douala, Cameroon \\ Email: *filsonana@yahoo.fr
}

How to cite this paper: Onana, F.M., Tamsa, A.A., Tchakonte, S., Koji, E., Nyamsi Tchatcho, N.L., Nkouefuth Nfongmo, Y. and Zebaze Togouet, S.H. (2021) Effects of Industrial Agriculture and Urbanization on Structure and Functional Organization of Macroinvertebrate of Coastal Streams in Cameroon. Journal of Water Resource and Protection, 13, 154-171. https://doi.org/10.4236/jwarp.2021.132009

Received: January 7, 2021

Accepted: February 23, 2021

Published: February 26, 2021

Copyright (อ 2021 by author(s) and Scientific Research Publishing Inc. This work is licensed under the Creative Commons Attribution International License (CC BY 4.0).

http://creativecommons.org/licenses/by/4.0/ (c) (i) Open Access

\begin{abstract}
The impact of land use changes on watercourses is poorly documented in Cameroon. Therefore, this study examines the effects of agriculture and urbanization on water quality, the structure and functional organization of macroinvertebrates of streams in the coastal zone of Cameroon. Nine sampling stations including three per catchment area with different land occupations (agricultural, urban and forest) were selected. Benthic macroinvertebrates were sampled monthly from February to July 2018 and the physicochemical variables were measured simultaneously. The urban and agricultural streams showed highly polluted waters with high nutrient and suspended matter content, whereas the forest stream waters are moderately polluted. In addition, the hierarchical ascending classification indicated a proximity in water quality between the agricultural and forest streams for which the main physicochemical variables did not vary significantly. With regards to macroinvertebrates, the forest watercourse is characterized by the proliferation of pollution-sensitive taxa, high diversity indices and complex trophic structuring, indicating its good ecological status. In contrast the urban watercourse, heavily polluted is characterized by low diversity indices reflecting a simplification of the structure of stands dominated by the pollution-tolerant collector-gatherer stands. The majority of biological indices and functional feeding groups were not significantly different between the agricultural and forest streams, sug-
\end{abstract}


gesting a less pronounced impact of agriculture on macroinvertebrates. Our results showed that, riparian vegetation even though constituted of perennial crops, reduces the effects of agricultural inputs on streams and promotes the establishment of diversified macroinvertebrate communities.

\section{Keywords}

Industrial Agriculture, Urbanization, Macroinvertebrates, Water Quality, Riparian Vegetation, Perennial Crops

\section{Introduction}

Changes in land occupation are manifested by the gradual replacement of natural areas by agricultural areas [1], by the extension of artificial surfaces and associated infrastructures through urbanization [2]. These changes in land occupation have consequences on aquatic ecosystems, such as habitat fragmentation and the resulting effects on the viability of animal and plant population evolving in these habitats [3].

In industrialized countries, the impact of agriculture, urbanization, industrialization and poor waste management on aquatic environments are well documented [4] [5] [6] [7]. In Cameroon, on the other hand, studies are very patchy, with most of the work carried out so far having been limited to assessing the effects of urbanization on streams [8]-[13]. So far, no study has been devoted to assessing the effects of industrial agriculture on the ecological integrity of streams. Therefore, the present study was tackled under a comparative approach, which makes it possible to distinguish between the effect of industrial agriculture on watercourses and the effect of urbanization.

In this study, physico-chemical parameters of water and macro-invertebrates were used as indicators because of their predictable responses to changes in the catchment area [14] [15] [16]. Physico-chemical analyses provide information on the concentration of pollutants in a hydrosystem and thereby evaluating the environment capacity to host biocenosis. Among the freshwater biota, macroinvertebrates are good tools for stream monitoring because they occupy a wide range of trophic levels and are pollution tolerant, providing solid information for the interpretation of cumulative effects due to exposure to pollutants and their sedentary life style makes it possible to reflect the local conditions of the environment, and to give a significant image of the quality of the habitat over time [17] [18].

The main objective of this study is to assess the effects of industrial agriculture and urbanization on the assemblages and functional organization of macroinvertebrates in two streams (Ekouma and Tongo'o Bassa) using a forest stream (Miana) in the same ecological region as a reference. The specific objectives of this study are: 1) to determine the effects of industrial agriculture and urbanisation on stream water quality; 2) to identify the differences in macroinvertebrate 
community structures using biological indices and functional feeding groups between agricultural, urbanized and forest streams; 3) to establish relationships between biological indicators, functional feeding groups and water quality.

\section{Methods}

\subsection{Study Area and Sampling Stations}

Investigations were carried out in three streams (Miana, Ekouma, Tongo'o Bassa) located in the administrative zone of Littoral Region in Cameroon. Littoral Region has an equatorial climate of Guinean type and Cameroonian coastal subtype, with an annual average precipitation of about $4000 \mathrm{~mm}$ [19]. This climate has two main seasons, a long rainy season from March to November and short dry season from December to February. Temperatures vary between $23^{\circ} \mathrm{C}$ to $33.5^{\circ} \mathrm{C}$ with a monthly average of about $28^{\circ} \mathrm{C}$ [19]. Table 1 presents the characteristics of sampling stations.

The Miana stream is located in the district of Yabassi. Yabassi is one of the least populated districts in the Littoral region with 4.77 inhabitants per $\mathrm{km}^{2}$ and $85 \%$ of its surface area occupied by a dense primary forest composed of large trees. The main human activity in Yabassi is subsistence farming. Three sampling stations coded M1, M2 and M3 were positioned respectively in the upper, middle and lower sections of the Miana stream (Figure 1).

The Ekouma stream, located in the Njombe-Penja district which covers a surface area of about $260 \mathrm{~km}^{2}$. The population density in Njombe-Penja is 139.57 inhabitants per $\mathrm{km}^{2}$. The Ekouma watershed is mainly characterized by the presence of industrial plantations such as the "Plantation du Haut Penja" (PHP) which covers a surface area of about $70 \mathrm{Km}^{2}$. These industries mainly grow dessert bananas, rubber, pineapple, flowers and white pepper and using chemical

Table 1. Characteristics of the sampling stations.

\begin{tabular}{|c|c|c|c|c|c|c|c|}
\hline $\begin{array}{l}\text { Catchment } \\
\text { attribute }\end{array}$ & Land use & Latitude $\mathrm{N}$ & Longitude E & $\begin{array}{l}\text { Altitude } \\
\text { (m) }\end{array}$ & $\begin{array}{l}\text { Width } \\
\text { (m) }\end{array}$ & Depth (m) & $\begin{array}{l}\text { Dominant } \\
\text { Substrate }\end{array}$ \\
\hline \multicolumn{8}{|l|}{ Miana } \\
\hline M1 & Forest & $4^{\circ} 33^{\prime} 35.20^{\prime \prime}$ & $9^{\circ} 58^{\prime} 05.46^{\prime \prime}$ & 71 & 1.51 & 0.22 & Sand, gravel \\
\hline M2 & Forest & $4^{\circ} 30^{\prime} 40.80^{\prime \prime}$ & $9^{\circ} 57^{\prime} 24.68^{\prime \prime}$ & 34 & 3.44 & 0.33 & Sand, Sand \\
\hline M3 & Forest & $4^{\circ} 30^{\prime} 14.05^{\prime \prime}$ & $9^{\circ} 54^{\prime} 16.86^{\prime \prime}$ & 19 & 9.23 & 1.12 & Sand, Mud \\
\hline \multicolumn{8}{|l|}{ Ekouma } \\
\hline E1 & Agriculture & $4^{\circ} 38^{\prime} 44.21^{\prime \prime}$ & $9^{\circ} 40^{\prime} 32.35^{\prime \prime}$ & 154 & 2.87 & 1 & Pebble, Mud \\
\hline E2 & Agriculture & $4^{\circ} 37^{\prime} 17.03^{\prime \prime}$ & $9^{\circ} 41^{\prime} 35.62^{\prime \prime}$ & 111 & 4.78 & 1.4 & Boulders, sand \\
\hline E3 & Agriculture & $4^{\circ} 36^{\prime} 10.26^{\prime \prime}$ & $9^{\circ} 41^{\prime} 11.90^{\prime \prime}$ & 106 & 15.13 & 1.85 & Sand, Mud \\
\hline \multicolumn{8}{|l|}{ Tongo'o Bassa } \\
\hline $\mathrm{T} 1$ & Urban & $4^{\circ} 2^{\prime} 42.50^{\prime \prime}$ & $9^{\circ} 43^{\prime} 47.11^{\prime \prime}$ & 17 & 2.8 & 0.48 & Sand, Mud \\
\hline $\mathrm{T} 2$ & Urban & $4^{\circ} 3^{\prime} 52.00^{\prime \prime}$ & $9^{\circ} 44^{\prime} 6.55^{\prime \prime}$ & 11 & 12.5 & 0.81 & Sand, Mud \\
\hline $\mathrm{T} 3$ & Urban & $4^{\circ} 5^{\prime} 13.96^{\prime \prime}$ & $9^{\circ} 43^{\prime} 21.90^{\prime \prime}$ & 2 & 13.59 & 1.62 & Sand, Mud \\
\hline
\end{tabular}




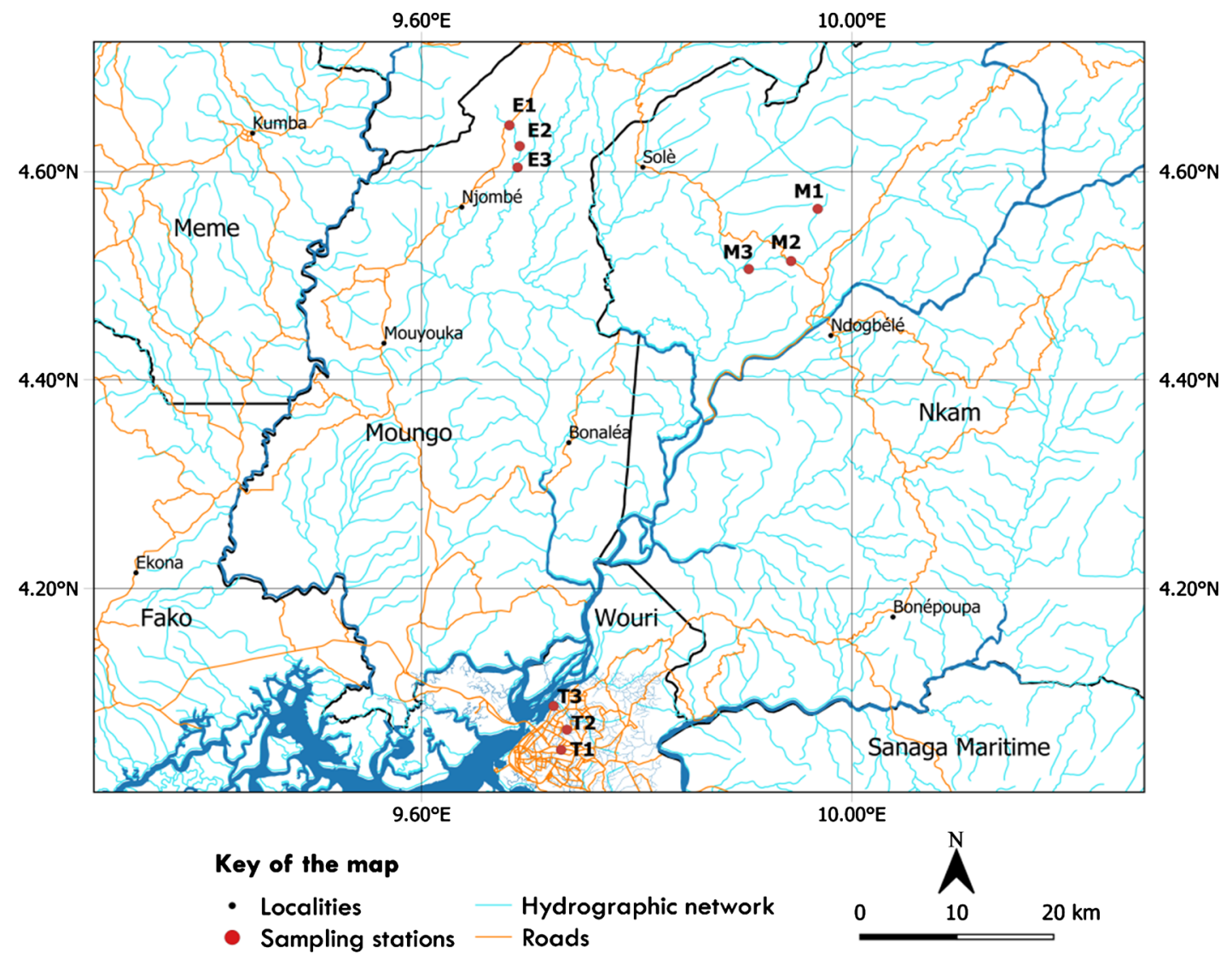

Figure 1. Map of the study area showing the different sampling stations.

fertilizers and pesticides. In the Ekouma stream, three sampling stations were also chosen (E1, E2 and E3) and located respectively in the upper, middle and lower sections of the stream (Figure 1).

The Tongo'o Bassa is the largest watershed among the 12 that make up the city of Douala. The harbor city of Douala is characterized by a fast and anarchistic urbanization, an increasingly demography (3033.59 inhabitants per $\mathrm{km}^{2}$ ), and an industrial sector in full expansion that generate wastewaters which are discharged into streams without any preliminary treatment. The Tongo'o Bassa catchment area is occupied by very unstructured neighbourhoods and is characterized by the presence of several markets and chemical food processing, textile and brewing industries. Three sampling stations were positioned on the Tongo'o Bassa stream: T1, T2 and T3 located respectively in the upper, middle and lower sections of the stream (Figure 1).

\subsection{Physicochemical Analyses}

Measurements of the physicochemical parameters were carried out monthly at each site from February to July 2018, between 6:00am and 9:00am, following the recommendations of Rodier et al. [20]. Physicochemical parameters like Water temperature (T), pH, Electrical conductivity (EC) and Dissolved oxygen (DO) were measured on site with a HANNA HI 9829 multi-parameter, because they 
are likely to change on transit to the laboratory. For physicochemical laboratory analyses, after the sampling in a pre-clean double-capped polyethylene bottle of $250 \mathrm{ml}$, water was preserved in refrigerated conditions at $4^{\circ} \mathrm{C}$ until variables such as Turbidity (Turb), Suspended Solids (SS), Orthophosphate $\left(\mathrm{PO}_{4}\right), \mathrm{Am}$ monium $\left(\mathrm{NH}_{4}\right)$ and Nitrite $\left(\mathrm{NO}_{2}\right)$ were measured in the laboratory, using a $\mathrm{HACH}$ DR/3900 spectrophotometer. Organic pollution was assessed using the Organic Pollution Index (OPI) which was calculated based of three ion concentrations $\left(\mathrm{NH}_{4}, \mathrm{NO}_{2}\right.$, and $\left.\mathrm{PO}_{4}\right)$ [21].

\subsection{Macroinvertebrates Sampling, Metrics and Indices}

Benthic macroinvertebrates were collected at each sampling station once a month between February and July, following protocols described by Starck et al. [22]. A long-handled kick net $(30 \mathrm{~cm} \times 30 \mathrm{~cm}$ side, $400-\mu \mathrm{m}$ mesh size and $45 \mathrm{~cm}$ of depth) was used in all the microhabitats (leaf packs, branches, macrophyte beds, sand, mud, pebble and rafts) of each sampling station. At each sampling station, macroinvertebrates were collected over a surface area of $6 \mathrm{~m}^{2}$ by making 20 drags of the kick net in all available micro-habitats, each drag consisted of pulling the net over a distance of approximately $1 \mathrm{~m}$, i.e. a surface area of $0.3 \mathrm{~m}^{2}$ for each drag. The collected macroinvertebrates were fixed with $70 \%$ ethanol and preserved in the plastic bottles. In laboratory, for each station, the animals were identified to the lowest possible taxonomic level under a stereomicroscope, with the use of appropriate taxonomic keys proposed by De Moor et al. [23], De Moor et al. [24], Tachet et al. [25] and Tachet et al. [26].

\subsection{Data Analyses}

The ecological integrity of the three studied streams was assessed by calculating 18 indices on the basis on abundances and taxonomic richness of macroinvertebrates, i.e.: 11 community structure indices, 5 functional feeding groups (FFG) and 2 diversity indices.

The community structure indices used in this study were: total number of individuals (TA); total taxa richness (S); Ephemeroptera-Plecoptera-Trichoptera (S-EPT), Plecoptera-Odonata-Ephemeroptera-Trichoptera (S-POET) and Diptera (S-Dip) taxa richness; relative EPT abundance (\%-EPT); relative abundance of Insecta (\%-Ins); relative abundance of Chironomidae (\%-Chir), relative abundance of Non Diptera Insecta (\%-N-Dip-Ins), relative abundance of Diptera (\%-Dip) and relative abundance of Oligochaeta (\%-Olig).

Concerning FFG, we used the classifications made by Mandaville [27], Cummins et al. [28] and Thorp and Covich [29] based on the mechanisms of obtaining food and the particle size of the food eaten to assign each organism identified to one of the five functional feeding groups (FFG): shredders (shr), scrapers (scr), collector-gatherers (c-g), collectors-filterers (c-f) and predators (prd). This functional approach examines changes in the trophic structure of the macroinvertebrate community of each ecological section of the watercourses. 
Lastly, two biodiversity indices (Shannon-Weaver's diversity index and the Piélou's evenness) were calculated, so as to highlight the numerical importance of taxa.

Hierarchical Cluster Analysis (HCA) was used to classify the sampling stations according to the physicochemical water quality of the 54 water samples collected during the 6-month study period. The physicochemical variables of the different clusters obtained by the HCA were compared using the Kruskal-Wallis test, after a study of the normality of the data by the Shapiro Wilk test. Assuming that abiotic water variables structure aquatic stands, statistical differences between macroinvertebrate indices of clusters identified by HCA were investigated using the Kruskal-Wallis test, after a study of the normality of the data by the Shapiro Wilk test. Potential links between physicochemical parameters and macroinvertebrate indices were searched using Pearson correlation test and $\mathrm{Ca}$ nonical Redundancy Analysis (RDA). The statistical analyses were carried out using the XLSTAT 2014 software.

\section{Results}

\subsection{Water Quality}

The HCA grouped the 54 water samples collected during the study into 3 clusters based on the physicochemical variables (Figure 2). Cluster I is composed of the 18 samples collected from the Tongo'o Bassa urban stream. Cluster II is made up of the 18 water samples from the forest stream Miana and cluster III is made up of the 18 water samples from the agricultural stream Ekouma.

Cluster II (Miana) groups globally the least polluted stations (moderate organic pollution) with less warm, well oxygenated, low mineralization and low organic matter (higher OPI) waters. Temperature and electrical conductivity

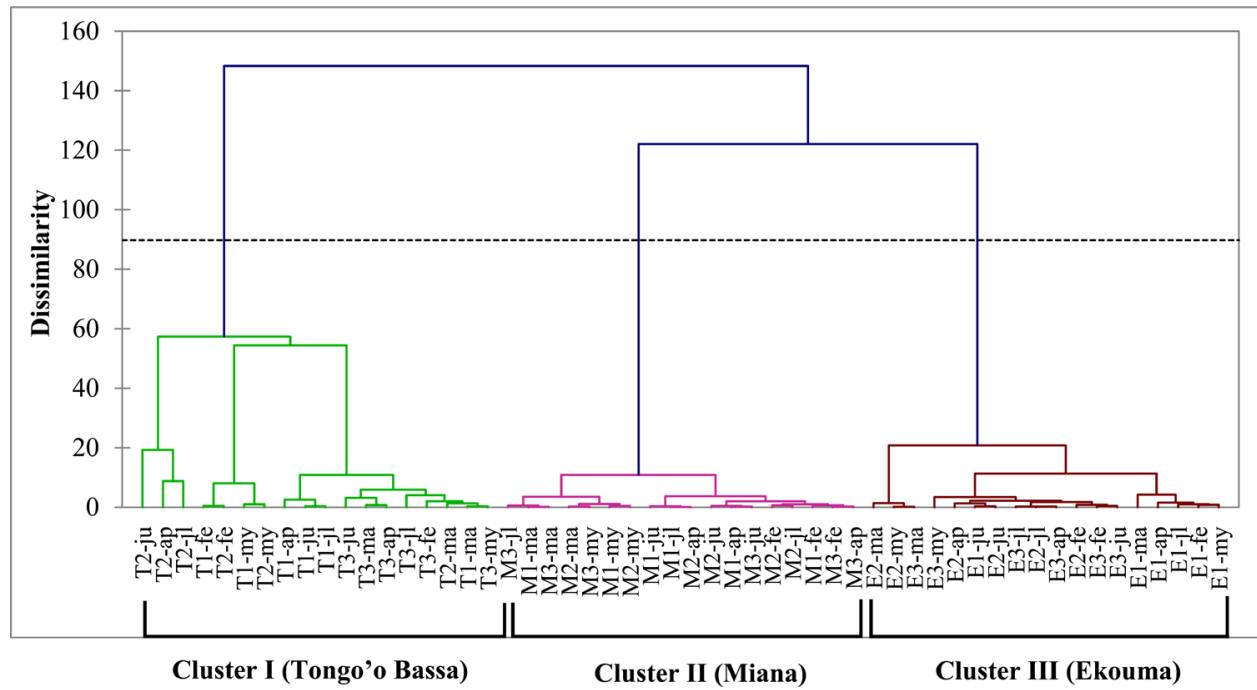

Figure 2. Classification of the sampling sites according to the physicochemical quality of the water of the 54 water samples collected during the 6 months of the study through a hierarchical cluster analysis, using the Bray-Curtis dissimilarity method (fe, ma, ap, my, ju and jl represent respectively sampling months February, March, April May, June and July). 
were significantly lower in Miana, while dissolved oxygen was significantly higher (Table 2). Cluster I, which comprises stations of the Tongo'o Bassa urban watercourse, had heavily polluted waters, with high turbidity, high organic matter loadings (lowest OPI) and low dissolved oxygen concentrations. Thus, values for turbidity, suspended solids, ammonium and orthophosphates are significantly higher in Tongo'o Bassa than in Miana and Ekouma (Table 2). Cluster III, which includes all the samples from the Ekouma agricultural stream, shows waters with significantly higher mineralization and an intermediate quality between that of the Miana and Tongo'o Bassa. In addition, the Kruskall-Wallis test revealed a certain proximity of water quality between the forest stream Miana and the agricultural stream Ekouma (Table 2).

\subsection{Macroinvertebrates Communities' Structure}

A total of 2562 macroinvertebrate individuals were collected from the three streams studied. They were divided into 50 taxa and grouped in 3 phyla (37 Arthropods, 7 Annelids, 6 Molluscs). 18 taxa have been identified at the species level, 28 taxa at the genus level and 4 taxa at the family level. The total taxonomic richness during the study in the Miana, Ekouma and Tongo'o Bassa streams were 16, 29 and 28 taxa respectively. In the Ekouma agricultural stream, no EPT taxa were inventoried, whereas in the Tongo'o Bassa and Miana streams, the number of EPT families recorded was 1 and 8 respectively. Thus, S-EPT is significantly higher in the forest stream Miana (Table 3).

Similarly, S-POET was significantly higher in Miana than in Tongo'o Bassa and Ekouma. S-EPT and S-POET did not differ significantly between Tongo'o Bassa and the Ekouma streams (Table 3). S-Dip, was significantly higher in Tongo'o Bassa, but does not differ statistically between Miana and Ekouma (Table 3).

Table 2. The status of water quality for cluster I, II and III derived from HCA.

\begin{tabular}{ccccc}
\hline \multirow{2}{*}{$\begin{array}{c}\text { Physicochemical } \\
\text { parameters }\end{array}$} & \multicolumn{3}{c}{ Clusters } & \multirow{2}{*}{ K-W } \\
\cline { 2 - 4 } & I (Tongo'o bassa) & II (Miana) & III (Ekouma) & \\
\hline $\mathrm{T}$ & $26.92 \pm 2.10^{\mathrm{a}}$ & $19.82 \pm 1.26^{\mathrm{b}}$ & $27.24 \pm 0.73^{\mathrm{c}, \mathrm{a}}$ & 35.40 \\
$\mathrm{pH}$ & $6.76 \pm 0.2^{\mathrm{a}}$ & $6.93 \pm 0.49^{\mathrm{b}, \mathrm{a}}$ & $7.68 \pm 0.49^{\mathrm{c}}$ & 23.31 \\
$\mathrm{DO}$ & $52.00 \pm 10.26^{\mathrm{a}}$ & $64.11 \pm 1.63^{\mathrm{b}}$ & $26.77 \pm 25.51^{\mathrm{c,a}}$ & 20.66 \\
$\mathrm{EC}$ & $341.46 \pm 132.53^{\mathrm{a}}$ & $23.04 \pm 3.27^{\mathrm{b}}$ & $5381 \pm 1207.71^{\mathrm{c}}$ & 47.13 \\
$\mathrm{SS}$ & $28.39 \pm 28.50^{\mathrm{a}}$ & $6.72 \pm 6.78^{\mathrm{b}}$ & $9.78 \pm 7.13^{\mathrm{c}, \mathrm{b}}$ & 18.69 \\
$\mathrm{Turb}$ & $34.28 \pm 25.19^{\mathrm{a}}$ & $2.61 \pm 3.31^{\mathrm{b}}$ & $9.83 \pm 10.35^{\mathrm{c}, \mathrm{b}}$ & 25.31 \\
$\mathrm{NO}{ }_{2}$ & $1.19 \pm 1.98^{\mathrm{a}}$ & $0.02 \pm 0.02^{\mathrm{b}}$ & $0.66 \pm 0.34^{\mathrm{c}, \mathrm{a}}$ & 23.01 \\
$\mathrm{PO}_{4}$ & $4.49 \pm 5.16^{\mathrm{a}}$ & $0.79 \pm 0.68^{\mathrm{b}}$ & $0.17 \pm 0.13^{\mathrm{c}, \mathrm{b}}$ & 25.47 \\
$\mathrm{NH}_{4}$ & $4.05 \pm 2.11^{\mathrm{a}}$ & $0.2 \pm 0.16^{\mathrm{b}}$ & $0.1 \pm 0.15^{\mathrm{c}, \mathrm{b}}$ & 37.40 \\
$\mathrm{IPO}^{2.06}$ & $2.06 \pm 0.72^{\mathrm{a}}$ & $3.41 \pm 0.59^{\mathrm{b}}$ & $2.96 \pm 0.44^{\mathrm{c}, \mathrm{b}}$ & 25.60 \\
\hline
\end{tabular}

Values represent mean \pm standard deviation. ${ }^{a, b, c}$ Differences among the three clusters as tested with the Kruskal-Wallis test. Values with different superscripts indicate significant differences. $\mathrm{p}<0.05$. 
Table 3. Macroinvertebrate indices for cluster I, II and III derived from HCA analysis. Values represent mean \pm standard deviation. Kruskal-Wallis $(\mathrm{K}-\mathrm{W})$ tests were used to evaluate differences among the three clusters.

\begin{tabular}{|c|c|c|c|c|}
\hline \multirow{2}{*}{ Metric } & \multicolumn{3}{|c|}{ Cluster } & \multirow{2}{*}{$\mathrm{K}-\mathrm{W}$} \\
\hline & I (Tongo'o Bassa) & II (Miana) & III (Ekouma) & \\
\hline \multicolumn{5}{|l|}{ Community structure Indices } \\
\hline S & $6.5 \pm 2.36^{\mathrm{a}}$ & $7.44 \pm 1.65^{\mathrm{b}, \mathrm{a}}$ & $5.11 \pm 1.81^{\mathrm{caa}}$ & 11.65 \\
\hline S-EPT & $0.06 \pm 0.24^{\mathrm{a}}$ & $1.67 \pm 1.19^{\mathrm{b}}$ & $0^{c, a}$ & 33.58 \\
\hline S-POET & $0.39 \pm 0.61^{\mathrm{a}}$ & $2.67 \pm 1.57^{\mathrm{b}}$ & $1.06 \pm 0.73^{\mathrm{caa}}$ & 23.06 \\
\hline S-Dip & $1.44 \pm 0.62^{\mathrm{a}}$ & $0.06 \pm 0.24^{\mathrm{b}}$ & $0^{c, b}$ & 47.82 \\
\hline TA & $77.33 \pm 45.66^{\mathrm{a}}$ & $28.28 \pm 12.36^{\mathrm{b}}$ & $36.72 \pm 15.98^{c, b}$ & 20.91 \\
\hline$\%$-EPT & $0.19 \pm 0.83^{\mathrm{a}}$ & $17.17 \pm 19.31^{\mathrm{b}}$ & $0^{\mathrm{c}, \mathrm{a}}$ & 33.83 \\
\hline$\%$-Ins & $50.55 \pm 25.89^{\mathrm{a}}$ & $48.41 \pm 20.80^{\mathrm{b}, \mathrm{a}}$ & $19.19 \pm 20.29^{c}$ & 18.60 \\
\hline$\%-N-D i p-I n s$ & $10.01 \pm 14.81^{\mathrm{a}}$ & $48.32 \pm 20.69^{\mathrm{b}}$ & $19.19 \pm 20.29^{\mathrm{c}, \mathrm{a}}$ & 24.32 \\
\hline$\%$-Dip & $40.54 \pm 27.31^{\mathrm{a}}$ & $0.09 \pm 0.39^{b}$ & $0^{\mathrm{c}, \mathrm{b}}$ & 48.61 \\
\hline$\%$-Chir & $38.81 \pm 27.49^{\mathrm{a}}$ & $0^{\mathrm{b}}$ & $0^{\mathrm{c}, \mathrm{b}}$ & 50.22 \\
\hline$\%$-Olig & $8.04 \pm 11.34^{\mathrm{a}}$ & $0.09 \pm 0.39^{b}$ & $0^{\mathrm{c}, \mathrm{b}}$ & 20.94 \\
\hline \multicolumn{5}{|l|}{ Diversity indices } \\
\hline $\mathrm{H}^{\prime}$ & $1.83 \pm 0.77^{\mathrm{a}}$ & $2.29 \pm 0.39^{\mathrm{b}}$ & $1.63 \pm 0.47^{c, a}$ & 13.72 \\
\hline $\mathrm{J}$ & $0.68 \pm 0.2$ & $0.8 \pm 0.10$ & $0.73 \pm 0.13$ & \\
\hline \multicolumn{5}{|l|}{ Functional feeding groups } \\
\hline$\%$-Shredders & $1.53 \pm 2.93^{\mathrm{a}}$ & $20.91 \pm 13.03^{\mathrm{b}}$ & $37.07 \pm 31.38^{\mathrm{c}, \mathrm{b}}$ & 18.98 \\
\hline$\%$-Scrapers & $1.3 \pm 2.95^{\mathrm{a}}$ & $22.64 \pm 26.57^{\mathrm{b}}$ & $36.06 \pm 39.57^{\mathrm{c}, \mathrm{b}}$ & 16.99 \\
\hline$\%$-Collectors-gatherers & $86.06 \pm 16.33^{\mathrm{a}}$ & $17.01 \pm 18.50^{\mathrm{b}}$ & $5.91 \pm 10.72^{\mathrm{c}, \mathrm{b}}$ & 37.59 \\
\hline$\%$-Collectors-filterers & $0.77 \pm 1.77$ & $0.28 \pm 1.18$ & $2.12 \pm 4.35$ & \\
\hline$\%$-Predators & $10.35 \pm 12.07^{\mathrm{a}}$ & $39.16 \pm 19.58^{\mathrm{b}}$ & $18.69 \pm 19.94^{\mathrm{c}, \mathrm{a}}$ & 20.43 \\
\hline
\end{tabular}

Values with different superscripts $(a, b, c)$ indicate significant differences. $\mathrm{p}<0.05$.

In terms of abundance, the urban Tongo'o Bassa stream has the highest total abundance (1392 individuals), with a strong proliferation of pollution-tolerant taxa such as Chironomus sp. (Chironomidae; $41.31 \%$ ) and Physa acuta (Physidae; $28.88 \%$ ). In the agricultural stream Ekouma (661 individuals), Caridina africana (Atyidae; 36.16\%), Biomphalaria pfeifferi (Planorbidae; 16.49\%), Melanoides tuberculata (Melaniidae; 12.71\%) and Cleopatra sp. (Thiaridae; 10.29\%) were the dominant taxa. In the forest stream Miana (509 individuals), Cleopatra sp. (Thiaridae; 23.38\%), Lymnaea natalensis (Lymnaeidae; 12.57\%), Caridina africana (Atyidae; 11.59\%) and Neoperla spio (Perlidae; 10.81\%) constituted the main part of the stand. \%-EPT and \%-N-Dip-Ins are statistically higher in the forest stream Miana than in the anthropized Tongo'o Bassa and agricultural stream Ekouma (Table 3). In contrast, \%-Chir, \%-Olig and \%-Dip were significantly higher in the urban Tongo'o Bassa stream, but did not differ statistically 
between the Miana and the Ekouma (Table 3). In addition, Chironomidae and Oligochaeta were not recorded in the agricultural stream Ekouma. Similarly, no Chironomidae were recorded in the forest stream Miana.

The Shannon and Weaver diversity index $\left(\mathrm{H}^{\prime}\right)$ was significantly higher in the Miana forested stream ( $2.29 \pm 0.39$ bits/ind.), whereas in the Ekouma agricultural stream, lowest values of this index were noted (1.64 \pm 0.47 bits/ind) (Table 3). In the urban stream Tongo'o Bassa, the H' value is $1.83 \pm 0.77$ bits/ind. Even though not varying statistically from one stream to another, the $J$ index revealed a better distribution of individuals within the stands of the Miana forest stream $(0.80 \pm 0.10)$. J values in the Ekouma $(0.73 \pm 0.13)$ and Tongo'o Bassa streams $(0.69 \pm 0.20)$ (Table 3$)$, reflected a poorer distribution of individuals within the taxa of these two anthropised streams.

\subsection{Distribution of FFG According to the Longitudinal Zonation of Watercourses}

The contributions of FFG to the macroinvertebrate community as a function of the longitudinal zonation (upper, middle and lower streams) of the Miana, Ekouma and Tongo'o Bassa streams are shown in Figure 3. In each of the sections, a simplification of the trophic structure of macroinvertebrates was observed with increasing pollution. In the superior section, if at M1 (Miana), shredders, scrapers, collector-gatherers and predators can be distinguished with

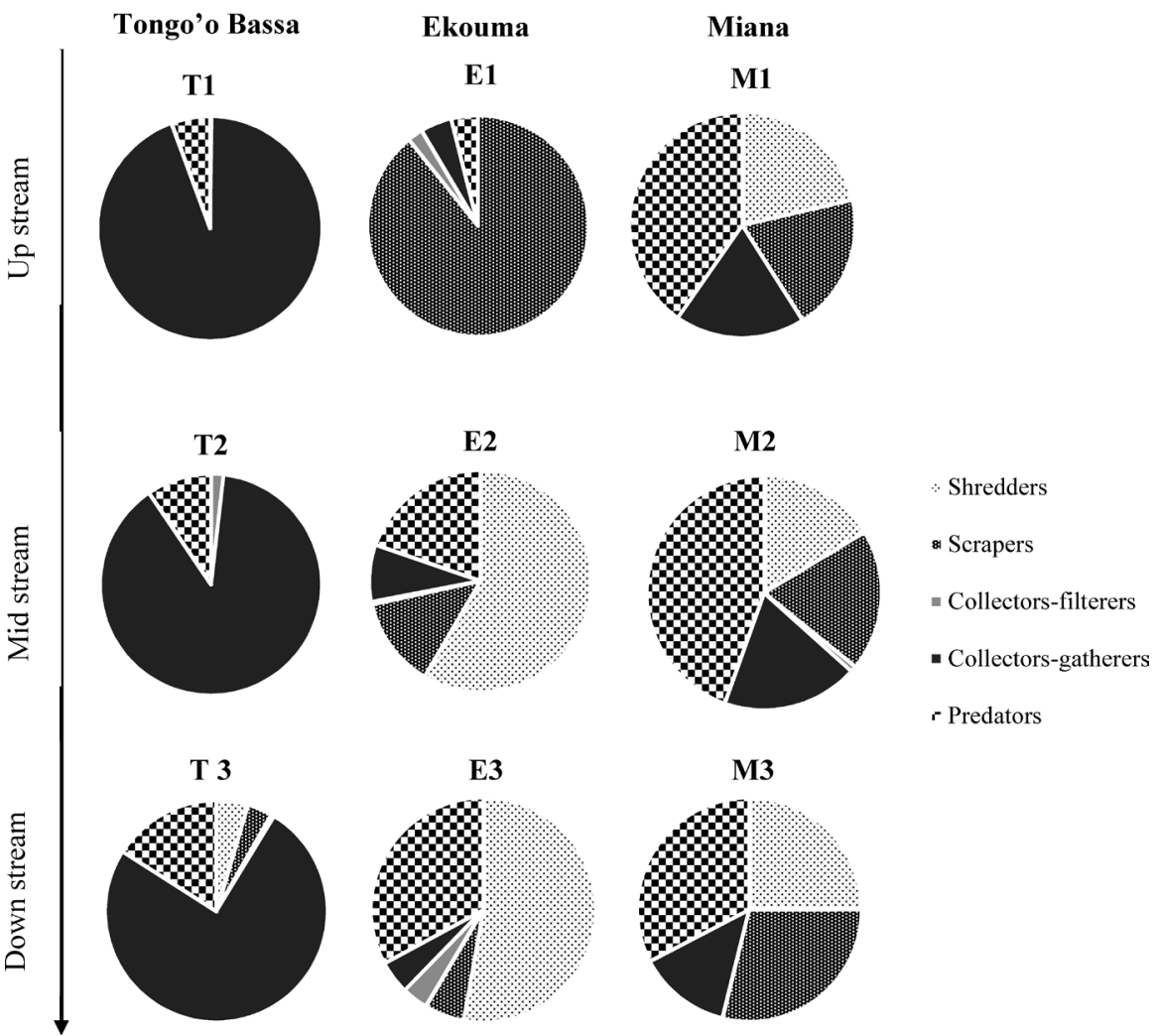

Figure 3. Relative contribution of trophic functional groups to benthic macroinvertebrate communities as a function of the longitudinal zonation of the rivers studied. 
relative abundances of $21.39 \% \pm 15.92 \%, 19.61 \% \pm 25.02 \%, 18.70 \% \pm 22.81 \%$ and $40.30 \% \pm 19.66 \%$ respectively, in stations E1 (Ekouma) and T1 (Tongo'o Bassa) one trophic group is largely preponderant. These involve scrapers $(89.25 \%$ $\pm 10.76 \%)$ at station E1 and collector-gatherers $(94.14 \% \pm 70 \%)$ at station $\mathrm{T} 1$. In their middle section, the Miana (M2) and Ekouma (E2) are dominated respectively by predators $(44.55 \% \pm 22.49 \%)$ and shredders $(58.40 \% \pm 20.37 \%)$. Other FFG can be distinguished in these two streams. Involving shredders $(16.35 \% \pm$ $10.33 \%)$, scrapers $(19.47 \% \pm 25.40 \%)$ and collector-gatherers $(18.80 \% \pm 17.76 \%)$ in the Miana, while in the Ekouma they are scrapers $(13.17 \% \pm 7.47 \%)$, collector-gatherers $(8.33 \% \pm 17.04 \%)$ and predators $(19.70 \% \pm 12.37 \%)$. Station T2 of the middle Tongo'o Bassa River is largely dominated by collector-gatherers $(88.70 \%$ $\pm 9.69 \%$ ). In the lower sections, in the Miana station (M3), individuals are mainly distributed in four FFG with relatively similar abundances: shredders $(24.99 \% \pm$ $13.09 \%)$, scrapers $(28.85 \% \pm 32.56 \%)$, collector-gatherers $(13.52 \% \pm 17.48 \%)$ and predators $(32.64 \% \pm 18.01 \%)$. At E3 (Ekouma), shredders $(52.81 \% \pm 21.00 \%)$ and predators $(32.90 \% \pm 26.25 \%)$ dominate the macroinvertebrates, while at $\mathrm{T} 3$ (Tongo'o Bassa), collector-gatherers $(75.34 \% \pm 22.93 \%)$ dominate. In the three land-use catchment areas, collector-gatherers are essentially dominated by Lymnaea natalensis (Lymnaeidae), Physa acuta (Physidae), and Chironomus sp. (Chironomidae), while the shredders are dominated mainly by Caridina africana (Atyidae) and predators are mainly composed of Odonata (Bratinopyga sp., Ictinogomphus ferox, Somatochlora pro parte, Cordulegaster sp. Coenagrion pro parte) and Hemiptera (Gerris sp., Ranatra linearis, Ilyocoris cimicoides, Plea sp., Rhagovelia reitteri).

Overall, collector-gatherers dominated significantly in Tongo'o Bassa urban stream where they represent $86.06 \% \pm 16.33 \%$ of benthic macroinvertebrates (Table 3 ). The scrapers and shredders comprised a significantly greater percentage at Ekouma agricultural stream than in Tongo'o Bassa urban stream, while predators, scrapers and shredders had a significantly greater percentage at Miana than in Tongo'o Bassa stream (Table 3).

\subsection{Relationships between Water Quality and Macroinvertebrate Metrics}

The main correlations between physicochemical parameters and macroinvertebrate indices are summarized in Table 4.

DO was positively and significantly $(\mathrm{p}<0.01)$ correlated with $\mathrm{S}$, S-EPT, S-POET, \%-EPT and \%-Ins. $\mathrm{NH}_{4}$ was negatively and significantly $(\mathrm{p}<0.01)$ linked with S-EPT, S-POET, \%-N-Dip-Ins, \%-Shr, \%-scr and \%-prd, but positively and significantly $(\mathrm{p}<0.01)$ correlated with TA, S-Dip, \%-Chir, \%-Olig, \%-Dip and \%-c-g. The same, $\mathrm{NO}_{2}$ showed negative and significant $(\mathrm{p}<0.05)$ correlations with S-EPT, but positive and significant $(\mathrm{p}<0.01)$ correlations with S-Dip, \%-Chir and \%-Dip. $\mathrm{PO}_{4}$ only showed positive and significant $(\mathrm{p}<0.01)$ correlations with S-Dip, \%-Chir, \%-Olig, \%-Dip and \%-c-g. Turbidity showed negative and significant correlations with indicators of good water quality such 
Table 4. Pearson's correlation coefficient between the physicochemical variables and biological metrics. Significant correlation ${ }^{*}$ : $\left.\mathrm{p}<0.05 ;{ }^{* *}: \mathrm{p}<0.01\right)$ are indicated by asterisk.

\begin{tabular}{|c|c|c|c|c|c|c|c|c|c|c|}
\hline Variables & $\mathrm{T}$ & $\mathrm{pH}$ & DO & EC & SS & Tur & $\mathrm{NO}_{2}$ & $\mathrm{PO}_{4}$ & $\mathrm{NH}_{4}$ & OPI \\
\hline S & $-0.281^{\star}$ & -0.129 & $0.355^{* *}$ & $-0.423^{\star *}$ & 0.086 & 0.174 & -0.033 & 0.087 & 0.041 & 0.039 \\
\hline TA & $0.329^{\star}$ & -0.180 & 0.060 & -0.175 & 0.117 & $0.330^{*}$ & 0.250 & 0.218 & $0.597^{\star *}$ & $-0.455^{\star *}$ \\
\hline $\mathrm{H}^{\prime}$ & $-0.312^{\star}$ & -0.199 & 0.267 & $-0.319^{\star}$ & 0.006 & 0.024 & -0.148 & 0.014 & -0.078 & 0.203 \\
\hline S-EPT & $-0.722^{\star *}$ & -0.069 & $0.402^{* *}$ & $-0.412^{* *}$ & -0.194 & $-0.318^{*}$ & $-0.277^{*}$ & -0.116 & $-0.300^{*}$ & $0.393^{* *}$ \\
\hline S-POET & $-0.668^{* *}$ & 0.127 & $0.271^{\star}$ & -0.227 & $-0.296^{*}$ & $-0.364^{* *}$ & -0.251 & -0.201 & $-0.437^{* *}$ & $0.461^{\star *}$ \\
\hline S-Dip & $0.383^{* *}$ & $-0.380^{* *}$ & 0.108 & $-0.403^{* *}$ & $0.632^{* *}$ & $0.781^{* *}$ & $0.293^{*}$ & $0.471^{* *}$ & $0.679^{*}$ & $-0.577^{* *}$ \\
\hline$\%$-ЕРT & $-0.581^{\star *}$ & -0.070 & $0.324^{*}$ & $-0.318^{\star}$ & -0.135 & -0.247 & -0.214 & -0.084 & -0.233 & 0.265 \\
\hline$\%$-Ins & $-0.282^{\star}$ & $-0.358^{\star *}$ & $0.332^{*}$ & $-0.579^{\star *}$ & 0.114 & 0.061 & 0.113 & 0.173 & 0.244 & -0.137 \\
\hline$\%$-Chir & 0.245 & $-0.409^{\star \star}$ & 0.173 & $-0.341^{\star}$ & $0.365^{\star *}$ & $0.392^{\star \star}$ & $0.349^{* *}$ & $0.387^{\star *}$ & $0.621^{\star \star}$ & $-0.542^{\star \star}$ \\
\hline$\%-N-D i p-I n s$ & $-0.557^{* *}$ & 0.035 & 0.183 & $-0.269^{*}$ & $-0.277^{*}$ & $-0.361^{* *}$ & -0.235 & -0.216 & $-0.372^{* *}$ & $0.405^{* *}$ \\
\hline$\%$-Olig & 0.211 & -0.169 & 0.023 & -0.218 & 0.214 & $0.303^{*}$ & 0.160 & $0.386^{\star *}$ & $0.423^{\star *}$ & $-0.399^{* *}$ \\
\hline \%-Dip & 0.256 & $-0.417^{\star \star}$ & 0.170 & $-0.348^{\star *}$ & $0.399^{* *}$ & $0.426^{* *}$ & $0.356^{* *}$ & $0.400^{* *}$ & $0.632^{\star *}$ & $-0.551^{\star *}$ \\
\hline$\%$-shr & 0.028 & $0.589^{* *}$ & -0.183 & $0.326^{\star}$ & -0.209 & -0.206 & -0.130 & $-0.323^{\star}$ & $-0.470^{\star *}$ & 0.259 \\
\hline$\%$-scr & -0.097 & 0.063 & -0.204 & $0.497^{* *}$ & -0.228 & $-0.335^{*}$ & -0.115 & -0.257 & $-0.373^{* *}$ & 0.336 \\
\hline$\%$-c-g & $0.283^{*}$ & $-0.457^{* *}$ & 0.216 & $-0.500^{* *}$ & $0.415^{* *}$ & $0.545^{* *}$ & 0.265 & $0.494^{* *}$ & $0.782^{* *}$ & $-0.619^{* *}$ \\
\hline$\%-c-f$ & 0.164 & 0.204 & 0.057 & $0.304^{*}$ & 0.210 & 0.262 & -0.019 & 0.039 & -0.146 & 0.010 \\
\hline$\%$-prd & $-0.438^{\star *}$ & 0.042 & 0.106 & -0.217 & -0.221 & -0.315 & -0.170 & -0.169 & $-0.337^{\star}$ & $0.353^{\star *}$ \\
\hline
\end{tabular}

as S-EPT ( $\mathrm{p}<0.05)$, S-POET ( $\mathrm{p}<0.01)$ and \%-N-Dip-Ins $(\mathrm{p}<0.01)$, while the correlations between turbidity and polluted water indicators (S-Dip, \%-Chir, \%-Olig, \%-Dip and $\%$-c-g) were positive and significant $(\mathrm{p}<0.01)$. At the opposite, OPI, showed positive and significant $(\mathrm{p}<0.01)$ correlations with indicators of good water quality such as S-EPT, S-POET and \%-N-Dip-Ins, but negative and significant ( $\mathrm{p}<$ 0.01) correlation with polluted water indicators (S-Dip, \%-Chir, \%-Olig, \%-Dip and \%-c-g). Except for S-EPT and scr, SS showed significant correlations with the same metrics as turbidity. The temperature, negatively and significantly correlated with S ( $p<0.05) ; \mathrm{H}^{\prime}(\mathrm{p}<0.05)$, S-EPT ( $\left.<<0.01\right)$, S-POET ( $\left.<<0.01\right), \%$-EPT $(\mathrm{p}<0.01), \%$-Ins $(\mathrm{p}<0.05), \%$-N-Dip-Ins $(\mathrm{p}<0.01)$ and \%-prd $(\mathrm{p}<0.01)$, was positively and significantly correlated with TA $(\mathrm{p}<0.05)$, S-Dip $(\mathrm{p}<0.01)$ and \%-c-g $(\mathrm{p}<0.05)$. Except for shr, c-f and scr with which EC is positively and significantly correlated, all other significant correlations established between EC and macroinvertebrate metrics were negative.

The Redundancy analysis results (Figure 4) revealed that the relationships between the macroinvertebrate indices and the physicochemical variables of the sampled stations are explained by the first two axes $(\mathrm{F} 1=69.93 \% ; \mathrm{F} 2=17.48 \%)$ which accounts for $87.41 \%$ of the information (Figure 4). According to the first axis (F1), the Tongo'o Bassa stations are characterized by high concentrations of ammonium, orthophosphates and high turbidity, which are favourable for the 


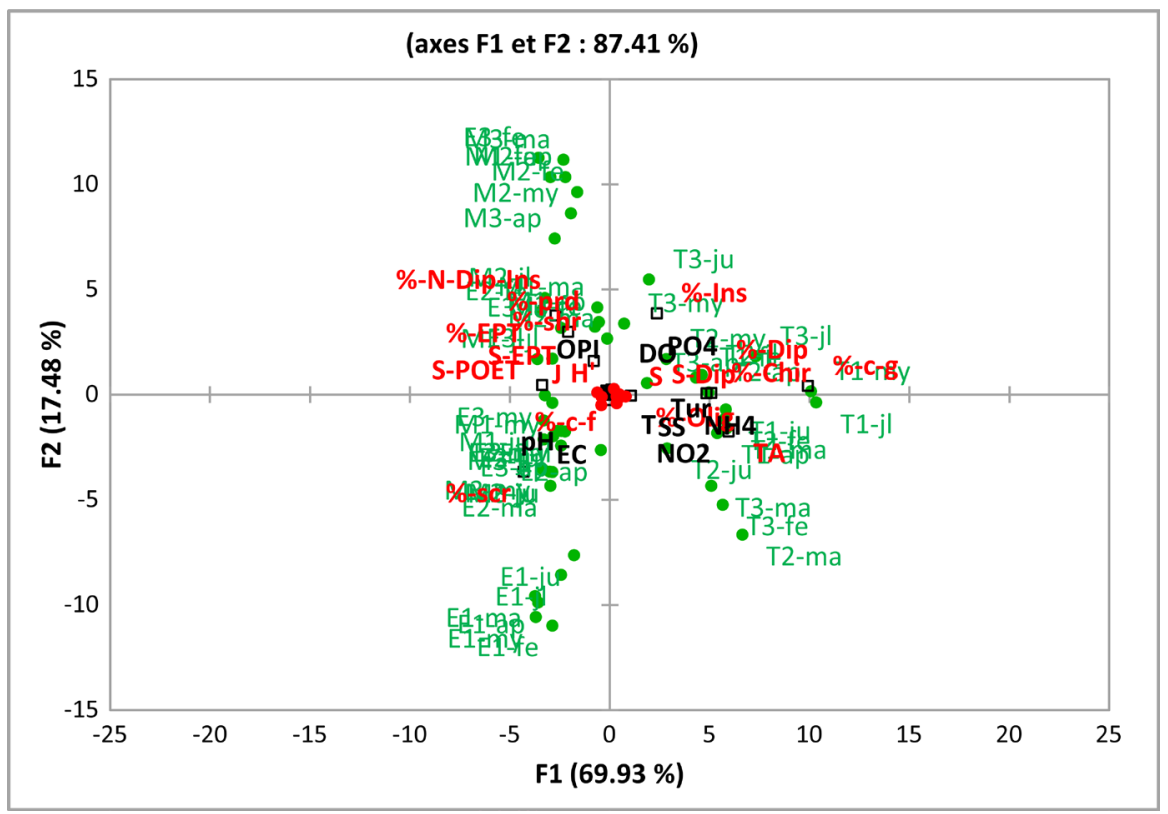

Figure 4. Redundancy analysis showing the relationships between macroinvertebrate metrics and environmental variables: see Figure 2 and "Materials and methods" section for abbreviations.

proliferation of Branchiura sowerbyi (Tubificidae), Chironomus sp. (Chironomidae), other Diptera and all the collector-gatherers taxa, mainly Physa acuta, Lymnaea natalensis and Sphaerium capense (Figure 4). Axis F2 shows that the proliferation of Ephemeroptera, Plecoptera, Trichoptera, Odonata and other non-Diptera Insects in the waters of the Miana forest stream is associated with their high DO and OPI values (low organic matter content) (Figure 4). Conversely, on the same axis and on the negative side, scrappers and collector-filterers seem to multiply in the waters of Ekouma, which are high electrical conductivity (Figure 4).

\section{Discussion}

\subsection{Water Quality}

The physico-chemical analyses indicated little difference between the water quality of the Ekouma agricultural stream and that of the Miana forest stream. This small difference would be linked to the presence of vegetation in the catchment areas of the two streams. Indeed, if in the Miana watershed a primary forest is observed, in the Ekouma watershed, the vegetation is linked to the presence of perennial crops. Such crops do not induce drastic changes in water quality, but like all riparian forests, they play an important role in the retention of pollutants, but less than that of primary forests. Riparian forests limit the exposure of watercourses to solar radiation, reduce soil erosion, and reduce the amount of nutrients and organic matter reaching the watercourses [30]. Gerth et al. [7], working in agricultural areas in Oregon (USA), showed that perennial plants reduce the effects of agriculture on streams. In contrast, the impact of ur- 
banisation on the Tongo'o Bassa urban watercourse is pronounced. The lack of vegetation in the Tongo'o Bassa catchment area, coupled with the discharge of untreated domestic, municipal and industrial wastewater seems to be responsible for the high concentrations of suspended solids, nutrients and organic matter. Hepp et al. [31], Tchakonté et al. [9] and Tchakonté et al. [10], in their studies carried out respectively in urban rivers in Brazil and Cameroon, implied that the same discharges changes the water quality in urban streams.

\subsection{Community Structure and Influence of Land Usage Types}

The forest stream Miana showed the highest diversity indices ( $\mathrm{H}^{\prime}$ and $\mathrm{J}$ ) and thus a better distribution of individuals within taxa. In contrast, the anthropised streams of Tongo'o Bassa and Ekouma showed lower diversity indices, indicating stands dominated by a small number of taxa. It is known that the destruction of riparian vegetation causes sediment discharge to watercourses, thus modifying their morphology, and the available substrates become more unstable and less complex, leading to a decrease in habitat diversity and trophic resources [15] [32]. For example, impacts in the urban Tongo'o Bassa stream, whose catchment area has been artificialized by the construction of urban infrastructures, are more exacerbated by various pollutants that are drained directly into the stream through runoffs. In the Ekouma stream, the impact of industrial agriculture on macroinvertebrates is less important because the perennial crops that occupy its watershed help to retain pollutants linked to the use of fertilizers and pesticides. Couceiro et al. [33] showed that deforestation and water pollution causes reduction in taxonomic abundance and a simplification of invertebrate communities. The results of the present study are similar to those obtained for other streams in the Araucanía Region, Chile [34] and for temporary streams in Oregon, USA [7].

The good ecological condition of the forest stream Miana is also highlighted by the preponderance of pollution-intolerant taxa such as EPT orders and non-Diptera Insects. Their pre-eminence in forest streams would be associated with the good oxygenation of their waters; hence, the positive and significant correlations between S-EPT, \%-EPT, \%-N-Dip-Ins and the high concentrations of dissolved oxygen. Our results corroborate those of Rios and Bailey [15] who showed that riparian vegetation increases the diversity of EPT taxa. However, the deterioration of the habitat quality of anthropised streams is demonstrated by the near absence of EPT taxa and Non-Diptera Insects, which are replaced by Chironomus sp. and Physa acuta in Tongo'o Bassa, and by Caridina africana, Melanoides tuberculata and Biomphalaria pfeifferi in the agricultural stream Ekouma. In fact, several studies have highlighted the role of the EPT orders as bioindicators of the good health of lotic hydrosystems [9] [35] [36], because the taxonomic richness and abundances of these animals decreases drastically in watersheds where urban pollutions are observed. In Tongo'o Bassa, high densities of Chironomus sp. and Physa acuta have been regarded as excellent bioindi- 
cators of poor water quality, in which the increase in their density is in response to organic enrichment by anthropic actions [25] [37]. Positive and significant correlations have thus been obtained between \%-Chir and organic matter indicators (Turb, $\mathrm{NO}_{2}, \mathrm{PO}_{4}$, and $\mathrm{NH}_{4}$ ). However, in the Ekouma stream, the dominant Caridina africana, Melanoides tuberculata and Biomphalaria pfeifferi are not classified in the literature as either tolerant or intolerant taxa [38]. Mandaville [27] give them an intermediate tolerance, between tolerant and intolerant taxa. Our results are in line with those of Hepp et al. [31], who describe intermediate models of macroinvertebrate communities in Brazilian agricultural streams, which fall between forest and urban river models.

Dosskey et al. [39] showed that, changes in ripaprian vegetation alter the amount of organic material entering aquatic systems, subsequently modifying the trophic structure of aquatic food webs. Thus, organic pollution derived from anthropogenic activities and the absence of riparian vegetation would be responsible for the marked alteration of the trophic structure of macroinvertebrate communities in the urban Tongo'o Bassa stream, where collector-gatherers, whatever the ecological section considered, are clearly favoured to the detriment of shredders, scrappers and predators that dominate in the Ekouma agricultural and the Miana forest streams. Indeed, collector-gatherers, which are predominant in Tongo'o Bassa, generally proliferate in aquatic environments with high loads of decomposing organic matter [28]. The relatively high abundance of shredders and predators is a typical characteristic of streams within forested regions [16] [40]. The variances between the trophic structure of Tongo'o Bassa and the Miana forest stream revealed a clear disturbance in the functioning of this urban watercourse. On the other hand, the trophic structures of the Miana and Ekouma streams differ slightly, which shows a lesser alteration of the Ekouma agricultural watercourse. Several studies have highlighted ruptures in the ecological discontinuity of benthic invertebrates along the longitudinal profile of streams by human activities [16] [41] [42] [43].

\section{Conclusions}

Ecological monitoring of forest, urban and agricultural streams has contributed to the understanding of the effects of different land uses on the biodiversity in lotic ecosystems of Cameroon. Physicochemical analyses have shown that, the waters of the urban stream are highly polluted with high concentrations of $\mathrm{NH}_{4}$, $\mathrm{PO}_{4}, \mathrm{NO}_{3}$ and SS. As regards the agricultural stream, although its waters are also highly loaded in organic matter, most of the values of the organic pollution parameters (Turb, OPI, SS, $\mathrm{NH}_{4}, \mathrm{PO}_{4}$ ) of this stream did not vary significantly from the values of the forest stream, whose waters are moderately loaded in organic matter. The macroinvertebrate communities of the forest stream are more diversified $\left(\mathrm{H}^{\prime}=2.29 \pm 0.39 ; \mathrm{J}=0.8 \pm 0.10\right)$, while that of agricultural $\left(\mathrm{H}^{\prime}=1.83\right.$ $\pm 0.77 ; \mathrm{J}=0.68 \pm 0.2)$ and urban $\left(\mathrm{H}^{\prime}=1.63 \pm 0.47 ; \mathrm{J}=0.73 \pm 0.13\right)$ streams communities are less diversified. As regard to FFG, forest and agricultural streams 
were dominated by 4 and 3 FFG respectively out of the 5 groups defined in this work. In the urban watercourse, only one FFG is widely represented with $86.06 \%$ of the individuals harvested.

Finally, the results of our study showed that the primary vegetation seems to support a good ecological status of forest streams with rich and diverse stands presenting a better distribution of individuals within taxa. In contrast, urban and agricultural impacts affect water quality and macroinvertebrates by reducing their diversity and simplifying their organizational and functional structures. However, while the impact of urbanisation on macroinvertebrates and water quality is more pronounced due to the artificialisation of watersheds that are completely deforested, the impact of agriculture on water quality and macroinvertebrates is less due to the presence of vegetation consisting of perennial crops that reduce the quantity of pollutants entering the watercourse.

\section{Acknowledgements}

The authors would like to thank the Department of Animal Biology and Physiology of the University of Douala in which the macroinvertebrate identifications were carried out. The authors would also like to thank the Cameroonian government, which partially financed this study through the special fund for the modernization of university research for the year 2018 .

\section{Conflicts of Interest}

The authors declare no conflicts of interest regarding the publication of this paper.

\section{References}

[1] Lepers, E., Lambin, E.F., Janetos, A.C., Defries, R., Achard, F., Ramankutty, N. and Scholes, R.J. (2005) A Synthesis of Information on Rapid Land-Cover Change for the Period 1981-2000. BioScience, 55, 115-124. https://doi.org/10.1641/0006-3568(2005)055[0115:ASOIOR]2.0.CO;2

[2] Vandevelde, J.C. (2014) Les instruments d'évaluation des impacts sur la biodiversité: Entre aménagement du territoire et conservation: Le cas des grands projets ferroviaires. Doctorat Thesis, University of Orleans, Orleans.

[3] Fahrig, L. (2003) Effects of Habitat Fragmentation on Biodiversity. Annual Review of Ecology, Evolution and Systematics, 34, 487-515. https://doi.org/10.1146/annurev.ecolsys.34.011802.132419

[4] Hepp, L.U. and Santos, S. (2009) Benthic Communities of Streams Related to Different Land Uses in a Hydrographic Basin in Southern Brazil. Environmental Monitoring and Assessment, 157, 305-318. https://doi.org/10.1007/s10661-008-0536-7

[5] Rasmussen, J.J., Baattrup-Pedersen, A., Wiberg-Larsen, P. and Kronvang, B. (2011) Buffer Strip Width and Agricultural Pesticide Contamination in Danish Lowland Streams: Implications for Stream and Riparian Management. Ecological Engineering, 37, 1990-1997. https://doi.org/10.1016/j.ecoleng.2011.08.016

[6] Moraes, A.B., Wilhelm, A.E., Boelter, T., Stenert, C., Schulz, U.H. and Maltchik, L. (2014) Reduced Riparian Zone width Compromises Aquatic Macroinvertebrate Com- 
munities in Streams of Southern Brazil. Environmental Monitoring and Assessment, 186, 7063-7074. https://doi.org/10.1007/s10661-014-3911-6

[7] Gerth, W.J., Judith, L. and Giannico, G.R. (2017) Agricultural Land Use and Macroinvertebrate Assemblages in Lowland Temporary Streams of the Willamette Valley, Oregon, USA. Agriculture, Ecosystems and Environment, 236, 154-165. https://doi.org/10.1016/j.agee.2016.11.010

[8] Foto Menbohan, S., Koji, E., Ajeagah, G.A., Bilong Bilong, C.F. and Njiné, T. (2012) Impact of Dam Construction on the Diversity of Benthic Macroinvertebrates Community in a Periurban Stream in Cameroon. International Journal of Biosciences, 11, 137-145.

[9] Tchakonté, S., Ajeagah, G.A., Diomande, D., Camara, I.A. and Ngassam, P. (2014) Diversity, Dynamic and Ecology of Freshwater Snails Related to Environmental Factors in Urban and Suburban Streams in Douala-Cameroon (Central Africa). Aquatic Ecology, 48, 379-395. https://doi.org/10.1007/s10452-014-9491-2

[10] Tchakonté, S., Ajeagah G.A., Camara, A.I., Diomandé, D., Nyamsi Tchatcho, N.L. and Ngassam, P. (2015) Impact of Urbanization on Aquatic Insect Assemblages in the Coastal Zone of Cameroon: The Use of Biotraits and Indicator Taxa to Assess Environmental Pollution. Hydrobiologia, 755, 123-144.

https://doi.org/10.1007/s10750-015-2221-5

[11] Onana, F.M., Zébazé Togouet, S.H., Koji, E., Nyamsi Tchatcho, N.L. and Tchakonté, S. (2016) Influence of Municipal and Industrial Pollution on the Diversity and the Structure of Benthic Macro-Invertebrates Community of an Urban River in Douala, Cameroon. Journal of Biodiversity and Environmental Sciences, 8, 120-133.

[12] Koji, E., Noah Ewoti, O.V., Onana, F.M., Tchakonté, S., Lontsi Djimeli, C., Tamsa Arfao, A., Bricheux, G., Sime-Ngando, T. and Nola, M. (2017) Influence of Anthropogenic Pollution on the Abundance Dynamics of Some Freshwater Invertebrates in the Coastal Area of Cameroon. Journal of Environmental Protection, 8, 810-829. https://doi.org/10.4236/jep.2017.87051

[13] Onana, F.M., Zebaze Togouet, S.H., Tamsa, A.A., Nyamsi Tchatcho, N.L., Tchakonte, S., Koji, E., Yemtsa Yemeli, A.W. and Mouto Makong, A.N.S. (2019) Comparing Freshwater Benthic Macroinvertebrate Communities in Forest and Urban Streams of the Coastal Ecological Region of Cameroon. Open Journal of Ecology, 9 , 521-537. https://doi.org/10.4236/oje.2019.912034

[14] Weigel, B.M., Lyons, J., Paine, L.K., Dodson, S.I. and Undersander, D.J. (2000) Using Stream Macroinvertebrates to Compare Riparian Land Use Practices on Cattle Farms in Southwestern Wisconsin. Journal of Freshwater Ecology, 15, 93-106. https://doi.org/10.1080/02705060.2000.9663725

[15] Rios, S.L. and Bailey, R.C. (2006) Relationship between Riparian Vegetation and Stream Benthic Communities at Three Spatial Scales. Hydrobiologia, 553, 153-160. https://doi.org/10.1007/s10750-005-0868-Z

[16] Zhang, Y., Zhao, R., Kong, W., Geng, S., Bentsen, C.N. and Qu, X. (2013) Relationships between Macroinvertebrate Communities and Land Use Types within Different Riparian Widths in Three Headwater Streams of Taizi River, China. Journal of Freshwater Ecology, 28, 307-328. https://doi.org/10.1080/02705060.2013.779941

[17] Barbour, M.T., Gerritsen, J., Snyder, B.D. and Stribling, J.B. (1999) Rapid Bioassessment Protocols for Use in Stream and Wadeable Rivers: Periphyton, Benthic Macroinvertebrates and Fish. U.S. Environmental Protection Agency, Washington DC.

[18] Gresens, S.E., Belt, K.T., Tang, J.A., Gwinn, D.C. and Banks, P.A. (2007) Temporal 
and Spatial Responses of Chironomidae (Diptera) and Other Benthic Invertebrates to Urban Stormwater Runoff. Hydrobiologia, 575, 173-190. https://doi.org/10.1007/s10750-006-0366-y

[19] Suchel, J. (1972) Les climats du Cameroun. Doctorat Thesis, University of Bordeaux III, Bordeaux.

[20] Rodier, J., Legube, B. and Merlet, N. (2009) The Water Analysis. 9th Edition, Dunod, Paris.

[21] Leclercq, L. and Maquet, B. (1987) Two New Chemical and Diatomic Indices of Running Water Quality. Application to Samson and Its Tributaries (Belgian Meuse Basin) Comparison with Other Chemical, Biocenotic and Diatomic Indices. Royal Institute of Natural Sciences of Belgium, Bruxelles.

[22] Stark, J.D., Boothroyd, K.G., Harding, J.S., Maxted, J.R. and Scarsbrook, M.R. (2001) Protocols for Sampling Macroinvertebrates in Wadeable Streams. New Zealand: Macroinvertebrates Working Group, Report No. 1, Ministry for the Environment.

[23] De Moor, I.J., Day, J.A. and De Moor, F.C. (2003a) Guides to the Freshwater Invertebrates of Southern Africa, Volume 7: Insecta I. Ephemeroptera, Odonata, Plecoptera. Pretoria: WRC Report No. TT 207/03.

[24] De Moor, I.J., Day, J.A. and De Moor, F.C. (2003b) Guides to the Freshwater Invertebrates of Southern Africa, Volume 8: Insecta II. Hemiptera, Megaloptera, Neuroptera, Trichoptera and Lepidoptera. Pretoria: WRC Report No. TT 214/03.

[25] Tachet, H., Richoux, P., Bournaud, M. and Usseglio-Polatera, P. (2006) Freshwater Invertebrates: Systematic, Biology and Ecology. CNRS Edition, Paris.

[26] Tachet, H., Richoux, P., Bournaud, M. and Usseglio-Polatera, P. (2010) Freshwater Invertebrates: Systematic, Biology and Ecology. CNRS Edition, Paris.

[27] Mandaville, S.M. (2002) Benthic Macroinvertebrates in Freshwaters-Taxa Tolerance Values, Metrics and Protocols. Soil and Water Conservation Society of Metro Halifax.

[28] Cummins, K.W., Merritt, R.W. and Andrade, P.C.N. (2005) The Use of Invertebrate Functional Groups to Characterize Ecosystem Attributes in Selected Streams and Rivers in South Brazil. Studies on Neotropical Fauna and Environment, 40, 69-89. https://doi.org/10.1080/01650520400025720

[29] Thorp, J.H. and Covich, A.P. (2010) Ecology and Classification of North American Freshwater Invertebrates. 3rd Edition, Academic Press, San Diego.

[30] Allan, J.D. and Castillo, M.M. (2007) Stream Ecology: Structure and Function of Running Waters. 2nd Edition, Springer, Dordrecht.

[31] Hepp, L.U., Milesi, S.V., Biasi, C. and Restello, R.M. (2010) Effects of Agricultural and Urban Impacts on Macroinvertebrates Assemblages in Streams (Rio Grande do Sul, Brazil). Zoologia, 27, 106-113. https://doi.org/10.1590/S1984-46702010000100016

[32] Orlinskiy, P., Münze, R., Beketov, M., Gunold, R., Paschke, A., Knillmann, S. and Liess, M. (2015) Forested Headwaters Mitigate Pesticide Effects on Macroinvertebrate Communities in Streams: Mechanisms and Quantification. Science of the Total Environment, 524, 115-123. https://doi.org/10.1016/j.scitotenv.2015.03.143

[33] Couceiro, S.R.M., Hamada, N., Luz, S.L.B., Forsberg, B.R. and Pimentel, T.P. (2007) Deforestation and Sewage Effects on Aquatic Macroinvertebrates in Urban Streams in Manaus, Amazonas, Brazil. Hydrobiologia, 575, 271-284.

https://doi.org/10.1007/s10750-006-0373-Z

[34] Fierro, P., Bertrán, C., Mercado, M., Peña-Cortés, F., Tapia, J., Hauenstein, E., Ca- 
puto, L. and Vargas-Chacoff, L. (2015) Landscape Composition as a Determinant of Diversity and Functional Feeding Groups of Aquatic Macroinvertebrates in Southern Rivers of the Araucanía, Chile. Latin American Journal of Aquatic Research, 43, 186-200. https://doi.org/10.3856/vol43-issue1-fulltext-16

[35] Molozzi, J., Hepp, L.U. and Dias, A.S. (2007) Influência da cultura de arroz sobre a comunidade bentônica no vale do Itajaí (Santa Catarina, Brasil). Acta Limnologica Brasilensia, 19, 383-392.

[36] Bacey, J. and Spurlock, F. (2007) Biological Assessment of Urban and Agricultural Streams in the California Central Valley. Environmental Monitoring Assessment, 130, 483-493. https://doi.org/10.1007/s10661-006-9438-8

[37] Virbickas, T., Pliūraité, V. and Kesminas, V. (2011) Impact of Agricultural Land Use on Macroinvertebrate Fauna in Lithuania. Polish Journal of Environmental Studies, 20, 1327-1334.

[38] MDDEFP (Ministère du Développement Durable, de l'Environnement, de la Faune et des Parcs) (2013) Guide de surveillance biologique basée sur les macroinvertébrés benthiques d'eau douce du Québec-Cours d'eau peu profonds à substrat grossier. 2e édition, Direction du suivi de l'état de l'environnement, Quebec.

[39] Dosskey, M.G., Vidon, P., Gurwick, N.P., Allan, C.J., Duval, T.P. and Lowrance, R. (2010) The Role of Riparian Vegetation in Protecting and Improving Chemical Water Quality in Streams. Journal of the American Water Resources Association, 46, 261-277. https://doi.org/10.1111/j.1752-1688.2010.00419.x

[40] Miserendino, M.L. and Masi, C.I. (2010) The Effects of Land Use on Environmental Features and Functional Organization of Macroinvertebrate Communities in Patagonian Low Order Streams. Ecological Indicators, 10, 311-319. https://doi.org/10.1016/j.ecolind.2009.06.008

[41] Benitez-Mora, A. and Camargo, J.A. (2014) Ecological Responses of Aquatic Macrophytes and Benthic Macroinvertebrates to Dams in the Henares River Basin (Central Spain). Hydrobiologia, 728, 167-178. https://doi.org/10.1007/s10750-014-1816-6

[42] Fierro, P., Bertrán, C., Tapia, J., Hauenstein, E., Peña-Cortés, F., Vergara, C., Cerna, C. and Vargas-Chacoff, L. (2017) Effects of Local Land-Use on Riparian Vegetation, Water Quality, and the Functional Organization of Macroinvertebrate Assemblages. Science of the Total Environment, 609, 724-734. https://doi.org/10.1016/j.scitotenv.2017.07.197

[43] Sabo, J.L., Caron, M., Doucett, R., Dibble, K.L., Ruhi, A., Marks, J.C., Hungate, B.A. and Kennedy, T.A. (2018) Pulsed Flows, Tributary Inputs and Food-Web Structure in a Highly Regulated River. Journal of Applied Ecology, 55, 1884-1895.

https://doi.org/10.1111/1365-2664.13109 